\title{
バイオメカニズム学会編集委員会 討論会
}

出摩者：飯田勝 (委員長)、石田明允 (副委員長)、大橋正洋、 高橋和久、立石折也、增田正、馬㴊清資、由中繁 (幹事)

\section{1. 編集委員を務めて}

【飯田】今日はどうもお忙しいところ、お集まり いただきありがとらございます。皆様この2 年間、 新しく編集委員をつとめられ、いろいろな御感想 をお持ちになられたことと思いますが、まずお一 人づつ擗をらかがいたいと思います。馬㴊委員 から㹉いいたします。

【馬㴊】大変勉強になりました。この学会につい て色々知ったといらことが勉強になったといらこ とと、もら一つは、雑誌といらものがどらいらも のなのか分かった、といらことです。これまで、 この学会はェレガンスな学会であり、あまり泥臭 いことはやっていないと思っていました。それが 案外臨床的なことも扱っている。また、自分がこ れまではただ単に書いていただけだったといらの が、編集する側の、すなわち雑誌を実際にまとめ ている側の方が何を考えているかといらことが分 かったのが、プラスになりました。

【飯田】次に高橋委員の御専門恃整形外科で、特 に筒椎のバイオメカニクスですが、初めて編集委 員をやっていただいての御感想はいかがですか。

【高橋】そらですね、文想像以上に大変な仕事 だなという感じを最初に持ちました。馬㴊委員と 同じように、このような編集委員会に参加したり、 雑誌を構成していくといら仕事は始めての経験で したし、どらいら特色を持たせるかとか、なかな か自分自身ではアイデアが思い浮かばないので、 大変だなあと思いました。しかし、編集委員をや らせていただいて、雑誌の組み方とか特集の選び 方などについては大変勉強になりました。

それから医学的な面の論文が、かなり取り上げ られてきましたので、少し我々にも理解できるも のが增えてきたなという感じを持ちました。率直 に申しますと、もら少しMに近いところも取り扱
らよらになれば我々医者にとっても理解し易い、 なじみやすいものになるのではないかと思います が。しかし、これは学会の伝統とか歴史があると 思うので、それはそれでよいのですが、アンケー 卜調查で医師が 20 人くらい回答しているというの も、一つそらいう医師の方妇分かりやすくなっ てきたといらことのあらわれでしょう。

【飯田】増田委員には人間工学的な立場からサポ 一トしていただいたのですが、臨床的な医学系と 基礎的な工学系の間をどう結び付けるかというこ とで御苦労はあったでしょらね。

【増田】あまりありませんでした。ただ、特集を 組むときに、「どの様な話が报もしろそらか」と いらことには興味はあるのですが、実際に書いて もらら場合に、「誰がどのようなことをやってい るのか」といらことを知らないものですから困り ました。その点については他の編集委員の方々に 教えていただいて助かりました。

【飭田】大橋委員はり八専門医で、その立場から 委員を務めていただきましたが、御感想はいかが ですか。

【大橋】私もバイオメカニズム学会のことを余り 知らなかったもので、ェンジニアの方と果してこ の雑訫の編集をどこまでできるのか、最初のうち は心配でした。しかし、飯田委員長が上手に方向 付けをしてくれたので、何とか仕事はできたと思 らのですが。私は出身がリハビリテーション医学 なのですが、りハビリテーション医学自体が比較 的新しく、リハビリテーション医学で患者をどの 様に直していくのかとか、その様なことをいつも 悩んでいます。ここにきてバイオメカニズム学会 の編集委員といらことになりますと、バイオメカ ニズムとはなんだろらということで、また㥗むよ らになりをした。 
特に、バイオメカニズムとリハビリテーション とはなんだろらということ、つまりバイオメカ二 ズムにどのようにリハビリテーション医学が関係 があるのだろらといらことの結論が出ないでいま す。ただ、編集委員をしてからといらのでは本当 は执かしいのでしょらが、いろいろな意味で視野 が広くなったことは有難かったと思っています。

【飯田】それでは立不委員の御感想をどらぞ。前 にも一度編集委員をやっていただいたのですが、 これまで臨朱系の方と度々一緒に仕事をされてお り、その利点欠点もよく解ってるといら点で、ま たぜひともと加わっていただいたのですが。

【立石】私のバックグラウンドは材料力学です。 材料力学というのをもっと正確にいいますと、固 体力学といらわけですが力学にはこの他に流体力 学とか熱力学と機械力学といらのがあります。そ れらのいわゆる力学の中で、材力は特に系統だっ た、すっきりした、整然とした学問なのです。そ らいう所にバックグラウンドを持っているので、 私が10年ちょっと㓩にバイオメカニクス学始めた ときに、非常に襍乱した領域に足を踏又入れたな といら気がしたのです。僕自身もバイオメカニズ ムとバイオメカニクスは大体同じように考えてい 李すが、バイオメカニズムはどちらかというと機 械工学でいうと、いわゆる機械力学とか機構学に 少し偏った領域であり、バイオメカニクスという のは固体力学とか流体力学とか、場合によっては 熱力学も入りますけれども、それにちょっと偏っ たものですが、当然峏者は才ーバーラップする訳 です。そういら考えが強いのです。

ですから、色々な機械工学の分野がありますが、 接頭語として“バイオ”を付ければ、それでバイ オメカニクスであるという考え方をしてしまうの です。ところが実際にはそうではないので、閳渕 委員が言われたけれども非常に混塱とした習慣に 馴染まないと、なかながイオメカニズムとかハ イオメカニクスとかは臨床家には役立つものには ならないのではないかといら気がするのです。し かし、どらしても長い間の習慣というものがあっ て、やはりバイオィカニズム学会のように非常に テーマが豊富で鼬沌とした所がやりき机ない、も
ら少しまとめたらどらかといら気もするのです。 今度 Vol. 11, No.1に編集後期を書けといわれ て、色々な関節の力学というものを統一するパラ ダイムというものができてきたのかな、といら感 想を書きました。10年前には研究者は全然いなか ったのです。それからすると、もう相当研究者む 増えて Eの方も増光たし、万法論としては少しら つ固まってきて、逆にいらと「体制化」されてき たのではないかという気がしますね。

\section{2. バイオメカニズムとバイオメカニクス}

【飯田】私も、単に会員になっていたときは、あ まり良く内容を知らなかったのが、編集副委員長、 次に委員長をやらせていただいて、やっとこの学 会のことが少しずつ分かってきました。これまで 参加してきた学会から比べると非常に幅の広い専 門分野の人がいる学会だというのは事実ですね。 それだけにまた、むずかしいと思いますね。全て の会員に興味を持ってもらえるようなことを企画 するのは実にむずかしく、この学会誌も非常に編 集がむずかしいだろうという感じもしました。

今日はひとつ学会誌だけについて話すのではな く、バイオメカニズムとバイオメカニクスといら ことの差についても話し合ってみたいと思います。 医学系からいいますと、バイオメカニズムという 菅葉にはなかなか近笴りがたいといら意識が働い て、中に入れないという感じがあります。学会誌 にしても内容がとっつきにくかったといら感じも あると思らのですが、いかがでしょう。このあた りの理解がなかなか抢互いにらまくいかないので はないでしょらか。

【立石】だから、きょらお集まりの編集委員の方 々も、昔から編集委員であったり、バイオメカニ ズムに関係したすはあまりいないわけです。3分 の 1 くらいではないですか。:゙イオメカニズムと いらのが、どちらかといらとロボットとかマニピ ュレータといった意味が強かったのです㸚。

「生体模倣」などと言うけれど、だいたいは口 ボットの制御を目指して、生体模倣をしているに 違いないと。まさか、医学まで考えてはないだろ らといら先入観を持っていましたね。で、実際に 
バイオメカニズムの会員、例えば機械技研を見ま すと、多くの人はロボット関係の人なのです。 (ロボット学会ができて) 大量に脱会したと思い ますが。

【田中】大量に脱会したといらことはないと思い ますが、徐々に入れ替えの起こっている可能性は あります。

【立石】そこでまた、例のバイオメカニズム学会 が論文誌を持たないということがでてくるのです 祆。結局論文誌を持たなくて 2 年に 1 回発表の場 を与えられると考えると、これだけでは強固な基 盤とはいえませんね。ロボット学会の方は論文誌 を持っているのですね。そのへんの方針というも のが、研究者としては積極的にこの学会を利用す るといら意味では不十分であると思います。

【大橋】今話をしているテーマといいますか、バ イオメカニズム学会、あるいはバイオメカニズム についての言葉といらことと、また学会誌の役割 についてとがあると思らのですが。バイオメカニ ズム学会に対して学会誌はどの様な役割をしなけ ればならないかといらことで、編集委員の顔ぶれ を見ても従来バイオメカニズム学会にかかわって きた人でもないし、その時に編集委員になった方 の顔ぶれで、その学会誌の内容が決ってしまうよ らなことがあるわけですけど。

また、学会の学会誌であるといらならば「本来 どらいら学会であるか」とか、「学会はどらいう よらにしたいか」ということがあって、その線に 沿って学会訫の内容も組まれていたほうがよいの かな、といら気はするのですが。そのために具体 的にどらするかといらと、例えば一つの基盤とし てシンポジウムとか学術講演会があるのだから、 それともっと有機的に結び付けて、例えば学術講 演会でどの様な演題が出たかというようなことに ついては、学会誌の方では全く揭載する機会がな いわけですし、また特集のテーマとかそら言うこ とについても、その時のメンバーで決めていって しまらといら。それは、今後学会誌の役割みたい なものは、もら少しはっきりさせた方がいい。

「バイオメカニズムはこういうものだ」といら ことを繰返し繰返し主張するというようなことは
必要ないのでしょうか。内容が学際的ないろいろ なものを選ぶよらになっているのですけれども、 果してそれがバイオメカニズムなのかどうか。ス ポーツからリ八医学から材料工学から、ありとあ らゆるものをまとめてその中心にあるのがバイオ メカニズムだといら図式になっていますけれども。 本来は身体から、生体から何かを学んで、それ をェンジニアリングに役立てるといら、そういう ことであれば非常に狭い範囲の学会になるのでし ょらけれども、このままだと本当に広い範囲の人 達がいろいろなテーマを載せるといらことになり かねないのですが。

【飯田】そらいらことからいらと、今大橋委員が いわ机よらにバイオメカニズム学会は非常に広 範な分野の人達の学会だから編集委員会も各分野 での持回りで、なんとなく一緒にやっているので すかね。やはり学会としての一つの研究的な柱を 出す出すといらのは、この学会誌ではなかなか難 しいということになります放。やはり会員は自分 の柱とする、ょり学問的な雑誌へ投稿して、バイ オメカニズム学会誌にはなかなか出さないという ことになるのでしょうかね。

【馬洋】学問かどらかといらことなのですね、煎 じ詰めていけば。学問といらのは、私の解釈では、 非常にレベルの高い哲学的な崇高さと実用性を持 っているものでないと、はやらないのですね。で 寸から、高等数学もあれば八百屋のそろばんもあ る、といら形をしているのですね、はやるものは。 バイオメカニクスは、どちらかといらとその実用 性だけで暮らしているようなところがあるのです ね、今は。ですから、それからもら少し何か抽出 されたものを、今難しいといわれているものは必 ずしも抽出されていないものです。ただ繁雑なだ けだといら気がする。そらではなくて、繁雑なの ではなくて、抽出されていて、例えばその手段を 使えば何でも問題を解決できるといらょうな意味 での、何といらか普遍性を持っていて、高いレベ ルのものが出てくれば自動的に普及するわけです から、そらいうものがほしいと思らのです。学問 の内容として。それが出てくれば、自動的にその 分野のある種のメインになるものが出てくること 
になると思うのです。

「バイオ」だから絶対「生体」といらことはど こかで引っかかっているのです。1つは。でもそ れだけだったら生物学であり、他の分野もいっぱ いある。それだけではなくて、それにプラスする ことのメカニズム、私は勝手にこれは力学だと訳 しているのですけれど。それが例えば材料学の方 からみても力学的な解釈のある、例妄ば材料力学 でなければいけないといら、そらいら様な気がし ているのです。

生体にある種の古典力学的な手法を応用したも のがこの様な領域を作っているのだろらと思うの です。そうすると、2つを結び付けるときにどこ が問題になるのか、といらことを考学るのが我々 のテーマだと、この学会に期待するものではない かと思らのです。そういらものは至るところで出 現してくるのです。それが捄そらく抽出されてい くべきものであろらと思います。例えばスポーツ 医学でも出てくるでしょうし、臨床の患者さんに 相い対するときにも出てくるのだろらと思うので す。その時に、こんな問題があるのです。

力学屋さんの考えている世界はとても現実離れ しています权。たとえば天文学ですと、10の何乗 といら話になります。また、絶対零度などという 話も出てきます。しかし、我々生体をやっている 人間にとると、それはどうでもいいのですよ。相 対論だとか、量子論だとかは出てこないのですか ら。そらすると、限定されたところだけが問題に なる。だけども簡単かといらと全然簡単じゃない わけです。相手に生のものが入ってくると急問 題たらけになってしまう。ですから、た之えば力 学ならば力学の持っている体系全体の中のある特 殊なところだけがもの凄く問題になって、しかも 逆にその中のつまらないことがえらく我々に取っ て重大であるといらことが扣きます。

その重要性は、そこに突然まったくの異分子が 入ってきたために起こるのだといらこと、そらい らことをつっつきまわしたらかなり括もしろいの ではないかと思います。

【高橋】多分医者の立場での考光方といらのは、 エンジニアの方とはかなり違うと思います。我々
の最終的な目的は医療に役立てるというのが全て となりますので。例えば、生物学的な様々な機構 を理解するといらよりも、理解したことによって 新しい診断とか、治療とかに結び付くということ が、最終的な目的としてあるのだろらと思います。 ですから、それに結び付计られる全ての材料をこ らいう領域から吸収寸るということが、我々医者 がバイオメカニクスを学ぶ目的なのです。だから、 ただ「知りたいから」というのとは違らのです。

最初、ある問題といらものがあって、それにア ブローチ寸るのにどのよらなものが使えるかとい らことが大切なのです。我々には物理学や数学の 全てを基礎から学といらことはとてもできません から、そらいら必要なものを吸収できて、どこに そういうものがありそうかといらことが分かるよ らなコミュニケーションの場がどうしてもほしい と思います。医者の側でもそれを理解するのに必 要な共通の言葉が分かるようになるまでは近付こ らといつも思っているのです。

【飯田】現在、整形外科バイオメカニクス研究会 がありますね。例えば、皆それだけではまだ物足 りないのか、それともそれで満足なのか。それが 問題で、もし満足ならばそこに留まっているので すね。やはり、もら一つ高いところを求めると、 こういうところに来なければいけないのですが、 現在の臨床ドクターはほとんど今のままで満足し ているのではないですか。

【高橋】バイオィカニクスといらと、医学とはか け離れたものと考光る臨床のドクターがまだいま 寸敞。10年前は汪とんどそういら人達ばかりだっ たと思らのですが。最近では少しは重要性という ものが分かってきて、ペーパーを書くときに修飾 的なものとして使らといらように。私はそれは間 違いだとは思らのですが、そらいら人が増えてき て少しは理解を示す人が増えてきています。それ から中には本当にそらいら方法論を使ってやって いこうといら人達が增えてきました。それはまあ、 病理学々か生理学々か生化学とかそれと同じです 权、基礎的な問をいかに臨床に役立てるかという 方法論です。

今饭田委員長がいいました、現状に満足かとい 
いますと、私自身は最近は非常にフラストレーシ ョンを感じています。それは自分がバイオメカニ クスにタッチしてきたこの10年間に、バイオメカ ニクスは進歩した工学的な手法を医学に取り入れ て急速に発展してきたよらに見えるのですが、10 年たってみてできることはそうとうやられちゃっ てる。け机ども依然として生物学的とか臨休的な 問題は残っていて、解決できないことは山ほどあ るという、ちょっと方法論的にいきづまっている といら感じが自分自身でもします。やれることは やってしまったけ机ぞも、令度もらちょっと本当 の問題の解決をしょうとする際に、これだけでい けるのかなということが今疑問なのです。

【飯田】それはまだ今のテクノロジーで可能か否 かを知らないといら閣題もあるかもしれません。

【高橋】そのと抢りです。私達の知り得ないコミ ュニターションのできない範眀にもっとよいもの があるのではないかといらことをいつも感じてい るのです。そこまで近づくの大変ですけれども。 【飯田】そうは思い军すが、現実には今整形外科 バイオメカニクス研究会に出ている臨林医とェン ジニアの方が、この学会で一緒にやれるわけでは ありません。そ机が問題です权。

【立不】それが問題なのですけど、整形外科バイ オメカニクス研究会ですが、これはどうしても

「臨床バイオメカニクス」ですね。ようするに何 か医学的に訳の分からないものに解を求め上うと して、一般解ではないけど特殊解があると、そし てそれをバイオメカニクスに求めようとしている のですよ。

【高橋】そこに私もいきづまりを感じているわけ です。有限要素法を関節に応用すれば、医者の思 らよらな結果が出てくるわけですよね。汪んとう にそれが真実かといらことはフィードバックをか けないと分からないのですが、そのフィードバッ クをかける方法が分からないのです。そのへんが 行き詰まりの理由なのです。

【立石】今の発棓は、だからバイオメカニズムの 存在意義といらことについて、いいところを突い ていると思うのですよ。臨床バイオメカニクスと いらのはどちらかといらと実学ですよね。それに
対してラショナル・バイオイカニズムといらもの もあるかもしれないと思らのです。本当に臨床的 な複雑な雑音に左右されない上らな、先汪ど馬㴊 委員のいったような、そら言ら何か一つの真理の 様な、バイオメカニズムの贲理というものが出て くる可能性があると。

というのは㸚、メカニズムという用語を医学の 方とか、体育の方とか、エンジニアが聞いたとき に、どの様に思らか。我々は「機構」というわけ です权。機構といらと、歯車とか何かごちゃごち やした物があって、寸分のくるいもないよらにき っちりと動くものがメカニズムなのですね。とこ ろが医学ではそれに対し、「機序」などといら言 葉があるでしょら。機序といらのは現象が流れて いる過程を、ブロセスをいらのではないですか。 我々がいら精密な「機構」というのは分からない わけですよ。

ただなんとなく流れていくから、「印象はどう ですか、言って下さい」といら医者の言葉で言う でしょら。ああいう感じのもの。医者のバックグ ラウンドとしてはメカニズムに対して、そういう 感じ方があるのではないでしょらか。それはそれ で結莓だと思うのですよ。皆そういらそれぞれ違 った感じすをもってバイオメカニズム学会に参加 して、しかも民主的に議論できますよ秝。

我々が整形外科バイオメカニクス研究会に行き ますと“縮み上がっている”のですよ。

【监田】逆にいらと、医者がつ学会では主体的 にはなれないと感じがするというのが一番の問題 で、この辺をなんとかしなければい汁ませんね。

【立不】だから、バイオメカニズムがそのへんを 救えるのではないかと。

【飯田】整形外科バイオメカニクス研究会に出て いくと確かに、あまりにも儖床に主を置いている か、基本的な、工学的手法を無視してしまい、そ らしたものはまったくどらでもいいといら基盤の 中で、医者はいきなり結果だけを全面的に信頼し ての議論が多いのですよ。だからそらいうところ の基盤が浅いというのを感じますね。やはりこれ はドクターももら一度少しきちんとこういうとこ ろに出て、基本的な問題をまず理解してからそう 
いらものに取り掛からなければいけないのではな いでしょらか。

ですからシンポジウムについても思らのですが、 本来的にはもっと丽しい意見をもらうためには、 参加しなければいけないのですよ枚形外科の ドクターは。逆な面もあるかも知れないのですね。

【立石】力学的な問題だけではなくて、ME学会 などでも熶近良心的な医者の掏らのは、ようする にェンジニアにあまりにも色々な臨床的な煩雑な 問題を押し付けて、エンジニアをだめにしてしま らといら、そういうことを文っている医者はけっ こういますよ、画像処理などでも。

だから、そこで打学的なバイオメカニズムに厌 るわけですけれども、やはりこの学会では括互い に調和のとれた、協力体制というものが必要だと。 そらすればこれからも存続すをのではないでしょ らか。

【大橋】それでは、ェンジニアの怆なぜバイオ に興味を持たれるのですか。

【増田】白動車とか飛行機之害った機械は人閏の 作ったものですから、ある意味では分かり尽くし ている护です。そ机に就して生物にはメカニズ ムはあるのだけれどあ、それが分からないという のが 1 つ面白さといらか、なにか夢がある点では ないでしょらか。

【大橋】何か害用的なものを作り出そうといらの ではなくて、とにかく研究のテーマとして俑白い とい5。

【増田】そうですね、好奇心といら意味で面回い のではないでしょらか。実用的に何か物を作ろら となったら、こんなことをやっていては時間の無 駄になるだけだと思らのです。

【馬㹸】いや、私はそらは思わないですね。最終 的には役に立つことをやっていると思らのです。 役に立つ、私の場合は臨床の役に立つといらこと を考えています。

【立不】臨林的にだけではなく、工業的に役立つ 真理が出てくるのではないか、というのはあるで しょ5。

【馬㴊】ありますね、私ははっきりと割り切って います。例えば人工関節を作るのは工業製品です
から工業なのですが、その最終目的が医学目的で あるわけですから、それはそれでよいのではない かと思うのです。但し他の医学と関係のない工業 製品に応用できることがあっても良いと思います。 だけど医学の目的を達成するための工業であると 思っているのです。

工学には目標が工羓製品でなければいけないと いら至上命令があります。そして厂学博士を取る とさに、「持ま之は一体どういら製品を作ろらと しているのか」を追求されるのですが。その時に その製品が飛行機であり、船であり、広範な人の ある種の要求に答之るものであってもいいじゃな いか、と私は思らのです。それが例えば飛行機を 作るときに何が間題で何がさづかし、というと

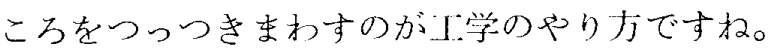
それと同じことをやっぱり人吅関節を作るとき、 あるいは人工の肖を作るとき、歯を作るときに、 つっつきまわさないと完成しないのではないかと いら気がするのです。それは特有なのです。特有 だからこの分野があるのではないかと思らのです。 この分野はそらいら特有性を持っているのだろら と考えるのです。

先はどの話に㞔りますが、だからといって臨休 の即物的な炭求に全部签えるのは、これは学問で はないと思らのです。それであったら学問の必琵 はないと焽らのです。それは戦なる情報の伝達機 関であればよいわけですから。今あるら学分野の 手法とか情報とかを全部流すバイプさえあればよ いのですから、それを学問にする必要はないので す。それ以上の水準はいらないのですから。だけ どもそれではできないことといらのがあります。 たとえば人工関節の間題です。現在その耐用年数 は20年といっています。今、酎用年数が20年など といら機械はほとんど無いですよ。車だって10年 立ったらがたがたになるのですから。あれは今の 科学水準から見ると最高級のものですから水。

で、自動車と人工関節は似たような条件にあり ます。非常に敢しい環境におかれて暮らしていま す。だから情報の横流しでは人工関節ができない。 そこで、我々バイオェンジニアの存在価值がどこ にあるかが明らかになってきます。ただのパイブ 
だったらそんなのは工学部の先生と、医学部の先 生が酒を飲んで遊んでいれば情報は流れるわけで すからそれでよいのです。我々のようなのはいら ないといらことになってしまう。

まったくの中間の領域で飯を食べたいと思った ときに何を考えるか。もちろんパイプにその様な 人間が必要だといえばそれまでなのですけど、学 問であろらとすると、それではすまない。たと光 ば人工関節を設計するためには、いま西る科学技 術を全部使ってもまだだめなんだと。そこでそれ を使った段階で、さらに何か新しいものを生んで なければだめなんだとなったときに、自分のやっ ていることは学問であろうと思っているのです。 そうするとそれは必ずしもすぐに峴実の問題に 答えるかどうかは分からないわけですよ、今度は。 無駄も出てきますからね。

\section{3。学会誌について}

【飯田】このバイオメカニズム学会というのもそ れぞれの会員が、意識的にどのあたりにメインを 置いているかといらことでアンケートを取ってい ただいたのです。

それぞれにメインの学会があって、さらに広い 交流を求めて入会しているといらのがアンケート から見ると非常に多いです权。オリジナルの論文 もイインの学会に持っていかれる感じがしますね。 学会誌に対象を絞っていきますと、これでいい といらことでしょらか。持回りで編集委員長が選 ばれて、 2 年間いろいろの特集でやっていく方向 でいいのでしょらかね。

【増田】特集自体は役に立っていると思います。 読んでも結構面白いですし。

【大橋】やはりバイオメカニズム学会の役割をど の様にするかといらことによって、学際領域のコ ミュニケーションだとすると、特集というのはす ごく面白いと思うのです。実際アンケートを見ま すと体育学に禹している力が 3 名しかおられない のに、特集の中で興味を持っているのが「スポー ッとバイオメカニズム」といらのが多いですから。 ご自分の専門外のことに興味を持って見ていらっ しゃるといらことでしょら。
【増田】工学の人間ですとスポーツ関係で論文を 読もうと思ってもなかなか大変ですから、ェンジ ニアとしても興味が持てるのではないでしょらか。 【飯田】確かに、我々も全部に目を通寸といらの ではなく、他分野の方々の仕事がどこかに出てい るとしても分からないことが多いのですよ称。従 って、特集でここに幅広く出していただければ、 非常に役立つといらのは確かだと思います。とい らことは、編集方針はべターだといらことになる のでしょらか。

【増田】「それでよい」といら話とは別だと思う のですが、役立つことは役立つのです。

【立石】バイオメカニズムに入っている人は汪之 んどプロパーの学会を自分で持っていてそこで発 表しているというでしょら、でしたらやめればい いのにやめないわけですよ㱛、3 百何十人かはず らっといるわけですから。何かあるのですね、こ のバイオメカニズムに対して、何か幻想を持って いるのですね。

【増田】やはり、何か新しいものができ上がって くるのではないかと、じっと見ているところでは ないでしょうか。

【立石】いろいろ理由はあるにせよ、いずれにし ても何かを期待していると思らのです。そこでも し、大きな学会ならば例えば学会の活性化とか、 学会誌の検討委員会などを作るわけですが、バイ オメカニズム学会の場合はその様な検討委員会を 作るほどの大きな勢力ではないから、どっちみち 編集委員会の意向で決っているのでしょう、学会 誌は。

【石田】アンケートにもありますが、「小さい学 会ですので小回りが効くのだ」と、そういら特徵 を生かして、もっと活性化するべきだという意見 が多いですね。

【飯田】活性化といらことは分かりましたが、活 性化の柱はなんでしょらね。実際の活動としては 学会誌と、シンポジウムが考えられますが。

【立石】やはりこれに原著論文を投稿できるのに、 投稿してこないといらのは活性化していないとい うことですから。 
【増田】学会誌には論文よりも、むしろコミュニ ケーションといらか、アイデアの投稿みたいなほ らが、活性化という意味では役に立つのではない でしょらか。論文といらのはできあがったもので すから。それよりも研究を始める前のアイデアの ようなものが載ると面白いと思います。

【大橋】特に、さきほどみたいにメカニズムを学 問のレベルで、医者としても深く知ってもらわな ければ困るといらことになると、なかなか臨床家 はそういら論文を書くというのは難しいですね。

【馬㴊】独自性は確かに良いと思います。なにし ろこの学会は他と同じではつまらんという方が多 いのですよ。私もそれでやっているのですが。そ らすると、システムも独自性でいこうということ にもなるのですね。そ㱛で、変わったシステムに なりましたよ悋。そういうのはいいですが、内容 が独自性があってシステムが他の学会と同じであ ってもいいと思らのですよ。

なにしろ、欧米には JOURNAL OF BIOMECHANICSやENGINEERING IN MEDICINE がある。日本だけにない、整形外科バイオメカニ クスがジャーナルだといえばそうなのですが。や はり巻・号のあるジャーナルといらのが得難いで すよね。それはある種の身だしなみだと思らので すよ。

【不田】でもちょっと心配なのは、ME学会等の 雑誌も諭文ばかりだったのですが、年に 1 回かな、 特集の出てくるのは。論文ばかりですとどらして もエンジニアの方が多くなるわけですよ、そうす るといくら見ても面白くないという話が出てくる わけですよ。特にMの方から、その辺をどら解釈 するかといらことですね。

そこで今度は分けてしまったのですよ、論文集 と学会誌というょうに。学会誌の方は解説記事に なっているのです。

【増田】それとは別に論文誌があるから、投稿は そちらにできるのですね。

【飯田】そうするとこの学会誌は、その中間辺り をいっていればいいのですかね。

【増田】論文ばかりになると読者が減ってしまう といらこともあり得るでしょう。
【立石】しかし、投稿もないのにそんな心配をす る必要もないのではないですか。

【焉洋】そういうことを促進したときにどらなる か、といら話をしているのですから。そらいら点 では、例えば臨休の関係のバイオメカニズムを載 せられるよらな枠を作ってしまったらどらですか。

【飯田】それも手だと思います福。これは此較的 新しいとか、これはと思ったら完成していなくて も研究といらのではなく、何かレポートの形で書 いてもらったらどらでしょうか。

【馬㴊】臨休雑誌ですと、はっきりと分けてあり ますよ权、例之ば論述というのがあって、臨床経 験といらのがあって、といらよらに。だから、あ の様な形でもいいのではないでしょらか。臨床経 験といら名前が良いかどうかは分かりませんが。 そらいらよらな分類を作って、生臭くてあまり学 術的ではなくてもか亦ない、としておく。

【大橋】学術誌を学会の活動と結び付けるのは、 学会の他のンンボジゥムとか学術講演会と有機的 に結びつける、今まで学会誌がその上うな特別な システムが無いとしたら、編集方針でそのンステ ムを変えることで、も5少し学会全体とも5少し 有機的に結び付けることができるかもしれないの です。例えば、学術講演会で発表されたものが投 稿する場所がない。ここへシステムとして場所を 作るなり、せめて発表された演題を載せるなり して、学年全体との流れを作ることはできると思 らのです。

【飯田】いずれにしても雑誌の方針として、解説

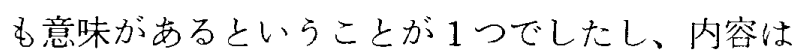
別としても研究的なオリジナル論文も望ましいと いらことでしょうか。今後はそのようになって注 しいといら感じでしょらか。

【馬㴊】研究を集めるのに、例えば「いま投稿さ れるとどのくらい先に載りますよ」といらことが 読者に伝わるといいですね。

【田中】それは以前に揭載したと思います。これ からも時々揭載する予定です。

【立石】理事会でも何回も出ていますよ水、ただ 1 度も実行されていないだけで。ですから、急に 論文が増えたら困るといらなら編集委員会の中で 
講㴤会の中からいいものを選んだらいい。学術满 演会の反省会も何もないわけですよ称。どらいう 方向に行ったかなど検討もできないし。

\section{4. まとめ}

【飯田】「学全誌はどうあるべきか」ということ については、大体我々の話の中で出ましたけ机ど も、やはりバイオメカニズム学会の活性化は、緗 集委員会がお秃いに発註することだといら結諭が 出てきました极。

【立石】そらです数、これから多いに発言しなけ ればだめですね、次期の編集委員は。

【飭田】このへんのデータを含めて、何が求めら れているのか、また「学際的なもの」あるいは

「接点」といったものを追求すれば、医学系の会 員がもっと增えるだろうという結果が此ていると 理事会で、いずれ報虽したいと琹います。

それでは最後にこの練集委員による討論会のま とめとしてお話をらかがいたいと思います。

【增用】2 年間やって、やっとちょっと㤨れてど らいらふらに進められるのかといらことが分か。 てきたところです。あと 2 年やれといわれても相 りますが。

あと、アンケートの中で「視点の広さ」という のが1つ書いてありますけれども。やはり狭いと ころに閉じこもらないで、拉㧍らかな感じがあっ てほしいと思います。

【馬㴊】私がこの分野をやり始めた頃は本当にわ ずかな人間しかおらずに、どちらかというと変わ り者扱いをされてきました。しかし、いまは世の 中がこういうオ面にけっこら理解があって、とい らよりブームに近いよらな事態です。だから、こ れから出てくる若い人達はもっとノ…ルなな秀才 が集まってくるんじゃないかと期待しています。

【大橋】いろいろなことを言ったので、特別なこ とはもう無いのですが、やはり学際領域というこ とに徹するのであればそれの良さをバイオメカニ ズム学会で追求するように、理事会とか編集委員 会の1つのまとまったす針として追求していただ けるといいと思います。

【立石】いろいろな学会の編集というものをやっ
てきましたけれども、今川のような編集委員会と いらのは初めて経験して非常に拈もしろいです。 やはりェキサイティングになるというのがいいで す㸚、きたんの無いところを訪充して。次の石 田委員舆に打いてもこういら状態をいつも作って いただきたいと思います。

【飯㽗】私も蛹集委員长をやってきまして、「こ らいらやり方でいいのか」といらことをいつも㥗 んでいました。そこで、皆样が編集委員を2年や ってこられて、「こんなふらにやったら」とか、 「こらいらものは大変だった」とかいらことが最 後に虬てくるのではないかと座談会を企画したわ けです。学会誌の今後の活性化内容の改善につな がっていけば幸いと思います。

まあこれまで、こういった意見があまり出ない ま末で、編集委員会にそのまま任されて特集だけ で 2 年間終り、次の委員会に渡していくという形 できたので、これを何とか少しでも変えたいと思 って企画したわけですが、皆様方のご協力で非常 に良い討論会ができたと思います。どうも本日は ありがとうございました。 